\title{
How Does the Digital Economy Affect the Domestic Value-Added Rate of Chinese Exports?
}

\author{
Yibing Ding, School of Economics, Jilin University, China \\ Hongyuan Zhang, School of Economics, Jilin University, China \\ Sitong Tang, Graduate School of Global Environmental Studies, Sophia University, Japan
}

\begin{abstract}
The digital economy continuously injects new momentum into the traditional economy and has become an important driving force for national economic development. Against this backdrop and using input-output data from the WIOD from 2002 to 2014, this paper empirically analyzes the impact of the development of the digital economy on the domestic value-added rate of Chinese manufacturing industry exports and the mechanism underlying this relationship. The results show that (1) digital economic input significantly promotes growth in the domestic value-added rate of manufacturing industry exports, (2) digital economic input mainly increases the domestic valueadded rate of intermediate-product exports, (3) digital input has a significant positive impact on the capital-intensive and knowledge-intensive manufacturing industries, and (4) technological progress and cost reduction are important mechanisms through which the digital economy promotes the domestic value-added rate of exports.
\end{abstract}

\section{KEYWORDS}

Cost Reduction, Digital Economy, Digital Inputs, Domestic Value-Added Rate of Exports, Global Value Chain, Manufacturing Industry, Technological Progress, Trade

\section{INTRODUCTION}

With a new generation of network information technology revolutions spreading around the world, the digital economy is booming. Led by innovations centered on digital networks, digital devices and digital information services, despite the overall economic downturn, the communications ecosystem is still creating channels for high growth (Hong, 2017). Between 2010 and 2015, the number of information and communication technology companies in the top 100 multinational companies doubled according to UNCTAD's 2017 World Investment Report (UNCTAD, 2017).

The research in this paper mainly focuses on China, which is an interesting and meaningful case study. First, China has gradually established its position as a digital innovation leader in the world through the rise of influential Chinese digital enterprises, including Baidu, Alibaba, Tencent and 
Xiaomi (OECD, 2017a). Second, the Chinese central government strongly supports the development of the digital economy. For example, the report of the 19th National Congress of the Communist Party of China clearly promoted the deep integration of the Internet, big data, artificial intelligence and the real economy, which makes up a large share of China's digital economy. By 2018, China's digital economy reached 31.3 trillion yuan, accounting for $34.8 \%$ of $\mathrm{GDP}^{1}$. More importantly, according to the PricewaterhouseCoopers Global Consumer Insight Survey (2019), China's mobile payment utilization rate has reached $86 \%$, ranking first in the world. Third, China's average labor productivity in the digital sector is higher than that of OECD countries, which indicates that the digital sector has a greater impact on the Chinese economy than on other economies (Garcia-Herrero,2018). Fourth, as a large, export-oriented developing country, China is more engaged in processing, assembly and other production links at the low end of the global value chain. Although China is the world's largest country in the trade of goods, the technical content and domestic value-added of its export products are relatively low, and most of its exports are final products with higher foreign value-added. At present, China urgently needs to adjust its export trade structure to ensure more real trade gains.

In the context of the current division of production in the global value chain and the vigorous development of the digital economy, this paper attempts to explore whether the digital economy can effectively improve China's domestic value-added rate of exports to obtain more real trade gains. If so, what are the specific channels by which the digital economy influences the domestic value-added rate of exports? Could the digital economy effectively promote the optimization and upgrading of China's export trade structure? Is the impact from the digital economy heterogeneous for industries with different factor intensities? The answers to these problems remain unclear. To solve these problems, this paper explores the influence of the digital economy on the domestic valueadded rate of total exports, the domestic value-added rate of intermediate-product exports, and the domestic value-added rate of final product exports. On the one hand, this research can help China's manufacturing industry obtain more real trade gains and optimize and upgrade its trade structure. On the other hand, research on Chinese issues can provide valuable insights for other export-oriented developing countries. Therefore, the research in this paper has important theoretical and practical significance for both China and the international community.

Some scholars have concluded that the Internet can promote Chinese exports. (Li \& Li, 2017; Shi \& Wang, 2018; Fernandes et al., 2019; Shen \& Yuan, 2020). Other scholars have used multinational panel data to examine the relationship between digital technology and trade. Abeliansky and Hilbert (2019) conducted a regression analysis of 122 countries and found that both the quality and quantity of information and communication technologies have a significant effect on export performance. Visser (2019) studied 162 exporters and 175 destinations, confirming that the addition of broadband networks has a positive and significant impact on export flows from low-income countries to highincome countries. However, each of these studies was conducted from the perspective of export flows or export performance without considering the domestic value-added rate of exports, so the impact on countries' real trade gains could not be explored. In this paper, measuring the relationship between the digital economy and China's domestic value-added rate of exports, including the domestic value-added rate of final product exports and the domestic value-added rate of intermediate-product exports, from the perspective of the global value chain is considered to be more practical. First, the authors examine the digital economy's impact on the domestic value-added rate of manufacturing exports. Second, to study China's trade structure, this paper decomposes the domestic value-added of exports into two forms-intermediate product domestic value-added and final product domestic value-added - and explores the role of the digital economy in improving the structure of the domestic value-added of manufacturing exports. Third, this paper conducts research at the meso-industry level, which helps to explore the heterogeneous impact of the digital economy on industries with different factor intensities. Finally, this paper explores the channels through which the digital economy affects the value-added of manufacturing exports from two aspects, technology progress effects and cost reduction effects, and conducts relevant tests. 


\section{THEORY AND HYPOTHESIS}

\section{Technology Progress Channels}

Herlitschka (2017) stated that "digital transformation brings significant changes in many areas of the economy and society, besting anything before concerning speed, range and impact". The development of the digital economy has produced and aggregated various factors for innovation and has also been a significant force in the promotion of technological progress. Due to the extensive coverage of the digital economy, this paper will analyze the internal mechanism by which digital economic development promotes technological progress, considering especially information and communication technology (ICT), artificial intelligence and the Internet.

In terms of information and communication technology, several points should be made. First, information and communication technology can be used as a production factor and in operational processes in order to exploit its potential to promote technological progress. Second, ICT could complement other production factors, leading to the optimal allocation of production factors and a corresponding adjustment in the organizational structure and further promoting the development of production technologies (Zhang \& Wei, 2019). Third, information technology could lead to technological progress in the industrial sector through mutual spillovers between information technology research, development and production departments and application departments.

Artificial intelligence (AI) could promote the technological progress of society through "machine learning" and could inspire support for innovative technologies despite the fact that AI itself is considered to be the result of continuous technological advancements (Brynjolfsson et al., 2017). Chen et al. (2019) confirmed through a dynamic general equilibrium model that artificial intelligence could help improve the speed of technological progress.

For the Internet, technology spillover effects are clearly observable (Ceccobelli et al., 2012; Xu, 2019). Therefore, the Internet could accelerate the spread and diffusion of information and technology, thereby helping promote the technological progress of enterprises (Dunnewijk \& Hultén, 2007).

By more deeply studying the relationship between technological progress and the domestic valueadded rate of exports, this paper finds that because technological progress is a critical driving force for the enhancement of China's endogenous economic growth capacity and is the foundation of China's independent development, such progress can enhance the degree of internalization of intermediate products and increase the domestic value-added rate of exports by adjusting the intermediate product allocation mechanism (Ma et al., 2019).

Research has indicated that technological progress is an important channel for growth in the domestic value-added of China's exports (Li \& Yao, 2015), and actively promoting technological progress is of considerable importance in increasing the share of the value-added of exports. Based on the above facts, the digital economy appears to have an effect on the domestic value-added rate of exports, which drives technological progress.

\section{Cost Reduction Channels}

The digital economy is characterized by rapid, efficient, convenient and low-cost information transmission. Against the backdrop of the digital economy, the manufacturing industry has shifted from a large-scale, standardized production model to a small-batch, personalized and flexible production model, which could save resources and result in cost reductions while meeting market demands for personalization (Liu, 2018). The concept of cost is comprehensive and varies according to business type. First, from the perspective of internal production and the operation of enterprises, Venables (2001) pointed out that the Internet can reduce production costs and organizational management costs for enterprises, as well as the search matching costs, communication costs and transportation costs not only between enterprises and upstream and downstream suppliers but also between enterprises and consumers. Yang and Liu (2018) believe that Internet-based e-commerce can not only significantly reduce marketing and other related costs but can also reduce the inventory costs of enterprises by 
means of big data analysis. Second, from the perspective of international trade, the existence and development of digital trade, expanded by big data and cloud computing, have greatly improved transaction efficiency and greatly reduced trade costs (Ma et al., 2019). In addition to reducing the production and transaction costs of enterprises related to international trade (Ramli \& Ismail, 2014), the Internet also reduced communication costs arising from linguistic dissimilarities (Visser, 2019).

In addition to Internet technologies, advanced information and communication technologies enable companies to conduct business operations and manage inventory more effectively, thereby reducing management costs (Tang et al., 2020). Blockchain technology can reduce transaction costs (OECD, 2017), and 3D printing technology can reduce manufacturing costs. These facts provide strong evidence for the role of the development of the digital economy in alleviating costs for manufacturing companies. In addition to the theory on the relationship between manufacturing costs and the domestic value-added of exports described above, some studies have demonstrated that an increase in production costs can reduce the domestic value-added of manufacturing companies' exports (Luo, 2019). Moreover, the decrease in business operating costs and the complexity of management can also help boost the domestic value-added of enterprises' exports (Xu et al., 2017). Therefore, the development of the digital economy appears to lower the costs of manufacturing and increase value-added, which translates into potential profitability. In other words, the digital economy reduces costs associated with the domestic value-added rate of exports.

In summary, the following hypothesis is proposed based on the channels by which the development of the digital economy influences the domestic value-added of exports:

Hypothesis One: The development of the digital economy promotes growth in the domestic valueadded rate of Chinese manufacturing exports.

Hypothesis Two: Technological progress and cost reductions are two important channels through which the development of the digital economy promotes growth in the domestic value-added of manufacturing exports.

\section{ECONOMETRIC MODELS, VARIABLES AND DATA}

\section{Econometric Model}

To effectively test the impact of the digital economy on the domestic value-added rate of manufacturing exports, the benchmark measurement model in this paper is set as follows:

$$
D V A R_{i t}=\alpha+\beta_{1} \operatorname{digital}_{i t}+\gamma X_{i t}+\delta_{i}+\delta_{t}+\varepsilon_{i t}
$$

$D V A R_{i t}$ represents the domestic value-added rate of exports in sector $\mathrm{i}$ in period $\mathrm{t}$, and its numerical value represents the real gains from trade in sector $i$ exports. According to the theoretical model, $\beta_{1}$ is expected to be a positive number. DVAR in the model can represent dvar (domestic value-added rate of total exports) and two variables that are decomposed to illustrate the trade structure: finr (domestic value-added rate of final product exports), and zjpr (domestic value-added rate of intermediate-product exports), which equals intr (DVAR of intermediate products absorbed directly into the importing country) + rexr (DVAR of intermediate products re-exported to a third country for absorption). The variable digital ${ }_{i t}$ represents the digital economy, that is, the digital inputs in sector $\mathrm{i}$ in period $\mathrm{t}$, and $X_{i t}$ is the set of control variables. $\delta_{i}$ and $\delta_{t}$ are industry fixed effects and year fixed effects, respectively, and $\varepsilon$ is a random error term. 


\section{Variable Description}

Explained variable: Domestic value-added rate of exports (DVAR). First, the gross trade accounting method from Wang et al. $(2013,2015)$ is used to measure and decompose the domestic value-added of exports and then the domestic value-added of exports is divided by the total value of exports to obtain dvar $=$ finr + zjpr $=$ finr + intr + rexr. Specifically, finr is the domestic value-added rate of exports in the form of final products; zjpr $=$ intr + rexr, which indicates the domestic value-added rate of exports in the form of intermediate products; intr is the domestic value-added rate of intermediate products that are absorbed directly by the importing countries; rexr is the domestic value-added rate of intermediate products that are re-exported by the importing country to a third country.

Core explanatory variable: Digital economy (digital). This paper mainly uses the definition of Knickrehm et al. (2016), which states that all the economic output brought by every type of digital input is the digital economy. Digital inputs include digital skills, digital equipment (hardware, software and communications equipment), and digital intermediates and services for production. Due to limitations in data availability, only the digital inputs of each sector are used to measure the digital economy. Digital inputs are measured as the intermediate inputs of the domestic communications industry (computer programming services, consulting services and other related information service activities provided to manufacturing sectors). (Li, 2018).

Control variables: a. R\&D intensity (rd). This measure is expressed as the ratio of the R\&D expenditures of industrial enterprises above a designated size to industrial sales output value. b. Size of the state-owned economy ( $\mathrm{gx}$ ). The ratio of the total value of the industrial output of state-owned industrial enterprises above a designated size to the total value of the industrial output of all industrial enterprises above a designated size is used to measure the size of the state-owned economy. c. Industry concentration (con). The ratio of the industrial sales output of large and medium-sized industrial enterprises to the industrial sales output of industrial enterprises above a designated size is used to represent industrial concentration. d. Foreign direct investment (fdi). This paper uses foreign capital and the share of capital from Hong Kong, Macao and Taiwan in total paid-in capital to measure the proportion of capital that is foreign. e. Human capital level (wage). The ratio of total labor compensation to the total number of persons engaged in various industries is used to represent the level of human capital at the industry level. f. Logarithm of capital investment (lncapital). The industry-level capital stock is used to represent capital investment, and it is measured by the perpetual inventory method with the formula: $K_{i t}=K_{i t-1}(1-\delta)+I_{i t}$. Here, $K_{i t}$ represents the fixed capital stock of industry $\mathrm{i}$ in year t. $I_{i t}$ is the fixed asset investment of industry $\mathrm{i}$ in year $\mathrm{t}$, which is expressed as the difference between the original value of the fixed assets in year $t$ and year (t-1) (Chen, 2011); then, the fixed asset investment price index is used to deflate this difference to constant prices with 2001 as the base period. $\delta$ represents the depreciation rate of the fixed assets. In this paper, following to the practice of Tian (2016), the depreciation rate of the manufacturing industry is set to 7.98\%. For the estimation of the capital stock in the base period, this paper draws on Hall and Jones (1999): $K_{i 2001}=I_{i 2001} /(\delta$ $+\mathrm{g}$ ), where $\mathrm{g}$ is the average annual growth rate of fixed asset investment in various industries from 2001 to 2014.

\section{Data Sources and Processing}

The data used in this study are from the World Input-Output Tables (WIOT) and Socioeconomic Accounts (SEA) in the World Input-Output Database (WIOD) from 2002-2014, the China Industrial Economic Statistical Yearbook from 2001-2014 and the China Science and Technology Statistical Yearbook from 2002-2014. The missing 2004 data are supplemented by the China Economic Census Yearbook 2004.

In addition, since the data released by WIOD in 2016 are based on ISIC Rev. 4.0 and do not directly correspond to the classification of industries in China's national economy, the sample data are processed into a unified industry classification system. In line with the National Economic 
Table 1. Descriptive statistics

\begin{tabular}{|l|l|l|l|l|l|}
\hline \multicolumn{1}{|c|}{ VARIABLES } & \multicolumn{1}{c|}{ N } & \multicolumn{1}{c|}{ mean } & \multicolumn{1}{c|}{ sd } & \multicolumn{1}{c|}{ min } & \multicolumn{1}{c|}{ max } \\
\hline digital & 221 & 0.133 & 0.154 & 0.007 & 0.895 \\
\hline dvar & 221 & 0.797 & 0.069 & 0.579 & 0.924 \\
\hline finr & 221 & 0.344 & 0.239 & 0.011 & 0.806 \\
\hline zjpr & 221 & 0.452 & 0.219 & 0.082 & 0.850 \\
\hline intr & 221 & 0.328 & 0.173 & 0.067 & 0.670 \\
\hline rexr & 221 & 0.125 & 0.062 & 0.015 & 0.282 \\
\hline fdi & 221 & 0.302 & 0.140 & 0.045 & 0.764 \\
\hline rd & 221 & 0.007 & 0.004 & 0.001 & 0.017 \\
\hline gx & 221 & 0.199 & 0.192 & 0.013 & 0.870 \\
\hline con & 221 & 0.560 & 0.176 & 0.198 & 0.908 \\
\hline capital & 221 & 0.452 & 0.466 & 0.015 & 2.515 \\
\hline wage & 221 & 0.366 & 0.298 & 0.058 & 1.711 \\
\hline cost & 221 & 1.783 & 0.080 & 1.545 & 2.061 \\
\hline tech & 221 & 1.341 & 0.452 & 0.679 & 2.629 \\
\hline
\end{tabular}

Industry Classification (GB/T4754-2002), industry matching was performed with ISIC Rev. 4.0, and 17 combined manufacturing industries were obtained.

\section{EMPIRICAL ANALYSIS}

\section{Benchmark Regression Results}

This paper first conducted a correlation analysis and variance inflation factor (VIF) test on the panel data, and no multicollinearity problems among the tested variables were detected. Furthermore, the Hausman test was also conducted on the model specification. The test result indicated that the null hypothesis should be rejected, which implies that a fixed-effects model was appropriate for the empirical analysis.

Columns (1) to (7) of Table 2 report the benchmark regression results for the impact of digital inputs on the domestic value-added rate of exports. Specifically, the explained variable in columns (1) to (3) is the total domestic value-added rate of exports (dvar). The regression results demonstrate that after adding control variables in column (3) and controlling for industry fixed effects and year fixed effects, the estimated coefficient of the digital economic variable increased, and the significance level increased from 5\% to $1 \%$. This indicates that the digital economy has significantly promoted the growth of the domestic value-added rate of manufacturing industry exports and verifies Hypothesis One. Moreover, the explained variables in columns (4) and (5) are the domestic value-added rate of final products (finr) and the domestic value-added rate of intermediate products (zjpr), respectively. The estimation results show that the digital economy has significantly increased the domestic value-added rate of intermediate-product exports and has improved the structure of the domestic value-added of exports, and the results are significant at the $1 \%$ level, which provides evidence that digital inputs could facilitate industrial upgrading and improve China's trade structure. Finally, the dependent variable zjpr is decomposed into intr and rexr in columns (6) and (7). The results indicate that digital inputs mainly boost the domestic value-added rate of intermediate-product exports that 
Table 2. Benchmark regression results

\begin{tabular}{|c|c|c|c|c|c|c|c|}
\hline \multirow{2}{*}{ VARIABLES } & (1) & (2) & (3) & \multirow{2}{*}{$\begin{array}{c}\text { (4) } \\
\text { finr }\end{array}$} & \multirow{2}{*}{$\begin{array}{c}\text { (5) } \\
\text { zjpr }\end{array}$} & \multirow{2}{*}{$\begin{array}{c}\text { (6) } \\
\text { intr }\end{array}$} & \multirow{2}{*}{$\begin{array}{c}\text { (7) } \\
\text { rexr }\end{array}$} \\
\hline & \multicolumn{3}{|c|}{ dvar } & & & & \\
\hline \multirow[t]{2}{*}{ digital } & $0.045^{* *}$ & $0.031 * *$ & $0.048 * * *$ & -0.021 & $0.068 * * *$ & 0.030 & $0.038 * *$ \\
\hline & $(2.41)$ & $(2.82)$ & $(3.86)$ & $(-1.68)$ & $(3.52)$ & $(0.93)$ & $(2.54)$ \\
\hline \multirow[t]{2}{*}{ Constant } & $0.832 * * *$ & $0.812 * * *$ & $0.757 * * *$ & $0.178 * *$ & $0.579 * * *$ & $0.440 * * *$ & $0.138 * * *$ \\
\hline & (122.09) & (18.16) & $(14.40)$ & $(2.30)$ & $(6.32)$ & $(5.24)$ & $(5.93)$ \\
\hline Control Variables & NO & YES & YES & YES & YES & YES & YES \\
\hline Industry FE & YES & YES & YES & YES & YES & YES & YES \\
\hline Year FE & YES & NO & YES & YES & YES & YES & YES \\
\hline Observations & 221 & 221 & 221 & 221 & 221 & 221 & 221 \\
\hline R-squared & 0.588 & 0.416 & 0.705 & 0.459 & 0.430 & 0.383 & 0.407 \\
\hline
\end{tabular}

Note: Robust t-statistics in parentheses, ${ }^{* * *} p<0.01,{ }^{* *} p<0.05,{ }^{*} p<0.1$.

are re-exported by the importing country to a third country, which further proves that digital inputs contribute to the optimization and upgrading of the manufacturing export structure.

\section{Heterogeneity Analysis}

The digital economy could have different effects on the domestic value-added rate of exports in sectors because heterogeneous effects may exist among industries with different factor intensities. Therefore, this paper classifies the manufacturing industry into labor-intensive industries, capitalintensive industries and knowledge-intensive industries following the methods of Fan et al. $(2016)^{2}$ and then conducts further empirical analyses of industry heterogeneity.

The regression results are shown in Table 3 below. The effect of digital inputs on the domestic value-added rate of exports differs by industry type. The results in column (1) show that, for laborintensive industries, the role of digital inputs has no significant positive impact and may even have

Table 3. Regression results for industries with different factor intensities

\begin{tabular}{|l|l|l|l|}
\hline \multirow{2}{*}{ VARIABLES } & \multicolumn{2}{c|}{ dvar } \\
\cline { 2 - 4 } & \multicolumn{1}{|c|}{ Labor-Intensive } & \multicolumn{1}{c|}{ Capital-Intensive } & \multicolumn{1}{c|}{ Knowledge-Intensive } \\
\cline { 2 - 4 } & \multicolumn{1}{|c|}{$(\mathbf{1})$} & \multicolumn{1}{c|}{$(\mathbf{2})$} \\
\hline digital & -0.090 & $0.035^{* * *}$ & $0.027^{*}$ \\
\hline \multirow{2}{*}{ Constant } & $(-0.30)$ & $(3.62)$ & $(2.30)$ \\
\hline & $0.596^{* *}$ & $0.904^{* * *}$ & $0.684^{* * *}$ \\
\hline Control Variables & $(5.44)$ & $(11.71)$ & $(8.37)$ \\
\hline Industry FE & YES & YES & YES \\
\hline Year FE & YES & YES & YES \\
\hline Observations & YES & YES & YES \\
\hline R-squared & 39 & 104 & 78 \\
\hline
\end{tabular}

Note: Robust t-statistics in parentheses, ${ }^{* * *} p<0.01,{ }^{* *} p<0.05,{ }^{*} p<0.1$. 
a negative impact. This phenomenon is probably due to the fact that labor-intensive industries, such as textiles, clothing and wood manufacturing, have less demand for digital inputs, and increased use of information technology inputs will offset the advantages of cheap labor $(\mathrm{Li}, 2018)$ and thus cannot significantly increase the domestic value-added rate of exports in those sectors. In contrast, the results in columns (2) and (3) illustrate that digital inputs have significantly positive effects on both the capital-intensive and knowledge-intensive manufacturing industries, which is consistent with other empirical evidence; that is, these two industries are relatively more affected by digitization and informationization.

\section{Endogeneity Test}

Although multiple control variables are included in the model, there are still potential endogeneity problems. On the one hand, reverse causality probably exists between digital inputs and the domestic value-added rate of exports. On the other hand, the digital economy and domestic value-added rate of exports are also affected by some common factors. Endogeneity problems caused by missing variables and reverse causality could lead to unreliable empirical regression results. In case of endogeneity problems and to ensure the robustness and reliability of the conclusions in the paper, the instrumental variable method and the panel generalized method of moments estimation technique are adopted to analyze the model, and the results are presented in Table 4 and Table 5. The first-order lag term of the digital economy variable was chosen as the instrumental variable.

Table 4 and Table 5 demonstrate that the results from regressing the digital economy on the domestic value-added rate of exports and its decomposition terms are basically consistent with the benchmark regression in columns (3) to (7) of Table 2. Furthermore, both the Kleibergen-Paap rk LM test and the Kleibergen-Paap rk Wald F-test results in Table 4 reject the null hypothesis that the instrumental variables are insufficiently identified and that the instrumental variables are weak. In Table 5, the Cragg-Donald Wald F-statistic shows that the null hypothesis of a weak instrument variable is rejected, and the Sargan statistic shows that our equation is exactly identified. Therefore, the results in Tables 4 and 5 together indicate that the chosen instrumental variables are reasonable, and the basic conclusions of this paper are still robust after addressing potential endogeneity problems.

\section{Robustness Tests}

To ensure the robustness of the regression results, this paper conducts two robustness tests.

First, this paper changes the measurement of the digital economy and uses the intermediate inputs of the global communication industry (computer programming services, consulting services and other related information service activities provided to the manufacturing industry) as the new

Table 4. Regression results that address endogeneity(IV)

\begin{tabular}{|c|c|c|c|c|c|}
\hline \multirow{2}{*}{ VARIABLES } & (1) & (2) & (3) & (4) & (5) \\
\hline & dvar & finr & zjpr & intr & rexr \\
\hline \multirow[t]{2}{*}{ digital } & $0.045 * * *$ & -0.024 & $0.069 * * *$ & 0.035 & $0.034 * * *$ \\
\hline & $(3.31)$ & $(-1.40)$ & (2.98) & (1.18) & (3.67) \\
\hline Control Variables & YES & YES & YES & YES & YES \\
\hline Industry FE & YES & YES & YES & YES & YES \\
\hline Year FE & YES & YES & YES & YES & YES \\
\hline Observations & 204 & 204 & 204 & 204 & 204 \\
\hline R-squared & 0.324 & 0.330 & 0.348 & 0.270 & 0.340 \\
\hline
\end{tabular}

Note: Robust t-statistics in parentheses, ${ }^{* * *} p<0.01,{ }^{* *} p<0.05,{ }^{*} p<0.1$. 
Table 5. Regression results that address endogeneity (GMM)

\begin{tabular}{|l|l|l|l|l|l|}
\hline \multirow{2}{*}{ VARIABLES } & \multicolumn{1}{|c|}{$(\mathbf{1})$} & \multicolumn{1}{c|}{$(\mathbf{2})$} & \multicolumn{1}{c|}{$(\mathbf{3})$} & \multicolumn{1}{c|}{ (4) } & \multicolumn{1}{c|}{ (5) } \\
\cline { 2 - 6 } & \multicolumn{1}{|c|}{$\mathbf{d v a r}$} & \multicolumn{1}{|c|}{$\mathbf{f i n r}$} & \multicolumn{1}{c|}{ zjpr } & \multicolumn{1}{c|}{ intr } & \multicolumn{1}{c|}{ rexr } \\
\hline digital & $0.038^{* *}$ & $-0.033^{*}$ & $0.071^{* * *}$ & 0.031 & $0.040^{* *}$ \\
\hline & $(2.34)$ & $(-1.66)$ & $(2.62)$ & $(1.46)$ & $(2.32)$ \\
\hline Control Variables & YES & YES & YES & YES & YES \\
\hline Industry FE & YES & YES & YES & YES & YES \\
\hline Year FE & NO & NO & NO & NO & NO \\
\hline Observations & 204 & 204 & 204 & 204 & 204 \\
\hline R-squared & 0.329 & 0.276 & 0.375 & 0.299 & 0.343 \\
\hline
\end{tabular}

Note: Robust $z$-statistics in parentheses, ${ }^{* *} p<0.01,{ }^{* *} p<0.05,{ }^{*} p<0.1$.

explanatory variable (global_digital). It is straightforward to see from a comparison of Table 2 and Table 6 that the robustness test regression results are basically the same as those obtained by the benchmark regression model, which provide strong evidence for the robustness of the model setting and the conclusions in this paper.

Second, this paper uses an alternative estimation method. Because the value of the explained variable is between $(0,1)$ and has an obviously limited range, the lower limit of the model is set to 0 , and the upper limit is set to 1 . The estimated results are shown in Table 7. It can be directly seen from a comparison of Table 2 and Table 7 that the regression results from the robustness test are consistent with the conclusions of the benchmark regression model, which once again provides strong evidence for the robustness of the model and conclusions of this paper.

\section{Mechanism Tests}

Following the theoretical analysis of the mechanism, this paper further examines the cost-reduction and technological-progress channels through which the digital economy affects the value-added of manufacturing exports. Based on research by Judd and Kenny (1981), Baron and Kenny (1986) and

Table 6. Results of the robustness tests (New Variables)

\begin{tabular}{|c|c|c|c|c|c|c|c|}
\hline \multirow{2}{*}{ VARIABLES } & (1) & (2) & (3) & \multirow{2}{*}{$\frac{\text { (4) }}{\text { finr }}$} & (5) & (6) & (7) \\
\hline & \multicolumn{3}{|c|}{ dvar } & & zjpr & intr & rexr \\
\hline \multirow[t]{2}{*}{ global_digital } & $0.044 * *$ & $0.032 * * *$ & $0.046 * * *$ & -0.020 & $0.067 * * *$ & 0.031 & $0.036^{* *}$ \\
\hline & $(2.52)$ & $(2.94)$ & $(4.09)$ & $(-1.62)$ & (3.59) & $(0.96)$ & $(2.29)$ \\
\hline \multirow[t]{2}{*}{ Constant } & $0.832 * * *$ & $0.813^{* * * *}$ & $0.758 * * *$ & $0.178 * *$ & $0.581 * * *$ & $0.441 * * *$ & $0.139 * * *$ \\
\hline & $(123.02)$ & (18.19) & (14.39) & $(2.28)$ & $(6.35)$ & $(5.26)$ & $(5.92)$ \\
\hline Control Variable & NO & YES & YES & YES & YES & YES & YES \\
\hline Control Industry & YES & YES & YES & YES & YES & YES & YES \\
\hline Control Year & YES & NO & YES & YES & YES & YES & YES \\
\hline Observations & 221 & 221 & 221 & 221 & 221 & 221 & 221 \\
\hline R-squared & 0.589 & 0.418 & 0.706 & 0.460 & 0.431 & 0.384 & 0.403 \\
\hline
\end{tabular}

Note: Robust t-statistics in parentheses, ${ }^{* * *} p<0.01,{ }^{* *} p<0.05,{ }^{*} p<0.1$. 
Table 7. Results of the robustness tests (Panel Tobit)

\begin{tabular}{|c|c|c|c|c|c|c|c|}
\hline \multirow{2}{*}{ VARIABLES } & (1) & (2) & (3) & (4) & (5) & (6) & (7) \\
\hline & & dvar & & finr & zjpr & intr & rexr \\
\hline \multirow[t]{2}{*}{ digital } & $0.042 * * *$ & $0.029 *$ & $0.046 * * *$ & -0.021 & $0.068 * * *$ & 0.029 & $0.038 * * *$ \\
\hline & $(3.25)$ & (1.92) & $(4.25)$ & $(-1.06)$ & (3.08) & (1.61) & $(5.15)$ \\
\hline \multirow[t]{2}{*}{ Constant } & $0.832 * * *$ & $0.840 * * *$ & $0.770 * * *$ & $0.178 * * *$ & $0.586 * * *$ & $0.448 * * *$ & $0.138 * * *$ \\
\hline & $(48.78)$ & $(26.82)$ & $(27.43)$ & $(2.62)$ & $(8.51)$ & $(8.06)$ & $(6.87)$ \\
\hline Control Variables & NO & YES & YES & YES & YES & YES & YES \\
\hline Industry FE & YES & YES & YES & YES & YES & YES & YES \\
\hline Year FE & YES & NO & YES & YES & YES & YES & YES \\
\hline Observations & 221 & 221 & 221 & 221 & 221 & 221 & 221 \\
\hline
\end{tabular}

Note: $z$-statistics in parentheses, ${ }^{* * *} p<0.01,{ }^{* *} p<0.05,{ }^{*} p<0.1$.

Wen et al. (2004), this paper constructs the following mediation effects model to test the underlying mechanisms:

$$
\begin{aligned}
& d \operatorname{var}_{i t}=\alpha+\beta_{1} \text { digital }_{i t}+\gamma_{1} X_{i t}+\delta_{i}+\delta_{t}+\varepsilon_{i t} \\
& \text { mediator }_{i t}=\alpha+\beta_{2} \text { digital }_{i t}+\gamma_{2} X_{i t}+\delta_{i}+\delta_{t}+\varepsilon_{i t} \\
& d \operatorname{var}_{i t}=\alpha+\beta_{4} \text { digital }_{i t}+\text { mediator }_{i t}+\gamma_{4} X_{i t}+\delta_{i}+\delta_{t}+\varepsilon_{i t}
\end{aligned}
$$

where $\mathrm{i}$ and $\mathrm{t}$ represent the industry and year, respectively; $\delta_{i}$ and $\delta_{t}$ are industry fixed effects and year fixed effects; $\varepsilon_{i t}$ is a random error term; and mediator represents the mediating variable. This paper uses data envelopment analysis (DEA) to measure the Malmquist productivity index ${ }^{3}$, decomposes the total factor productivity growth into a technological progress index and a technological efficiency growth index, and finally obtains the technological progress rate by multiplying cumulatively the technical progress index. Cost is the cost ratio, which is expressed as the ratio of the total costs in each manufacturing industry to the total output value. The costs include both the costs of the main business and the operating expenses. Operating costs are expressed as the difference between the income of the main business and the operating profits.

The test results for the mechanism by which the digital economy impacts the domestic valueadded rate of manufacturing exports are shown in Table $8^{4}$. Column (1) shows the impact of the core explanatory variable, digital economic inputs, on the domestic value-added rate of exports. Columns (2) and (3) are empirical tests of the rate of technological progress as an intermediate variable. The estimated coefficients on digital and tech are both significantly positive. These results imply three things: digital inputs have significantly boosted the rate of technological progress, technological progress is an important channel through which the digital economy promotes the domestic valueadded rate of exports, and the digital economy has technological progress effects on the domestic value-added rate of manufacturing exports. Columns (4) and (5) are empirical regressions that use the cost rate as an intermediary variable. The estimated coefficient on digital in column (4) is significantly negative, as is that on cost in column (5). The results show that digital inputs significantly reduce the cost and expense ratio of the manufacturing industry, which is an important channel by which the digital economy promotes the domestic value-added rate of exports. The results also show that the 
Table 8. Impact Mechanism Test: Mediation Effect Model

\begin{tabular}{|c|c|c|c|c|c|c|}
\hline \multirow{3}{*}{ VARIABLES } & \multirow[b]{2}{*}{ dvar } & \multicolumn{2}{|c|}{ Path 1} & \multicolumn{2}{|c|}{ Path 2} & \multirow[b]{2}{*}{ dvar } \\
\hline & & tech & dvar & cost & dvar & \\
\hline & (1) & (2) & (3) & (4) & (5) & (6) \\
\hline \multirow[t]{2}{*}{ digital } & $0.050 * * *$ & $0.438 * * *$ & $0.042 * * *$ & $-0.084 * * *$ & $0.043 * * *$ & $0.033^{* *}$ \\
\hline & (4.24) & $(4.42)$ & $(3.41)$ & $(-3.75)$ & $(3.50)$ & $(2.56)$ \\
\hline \multirow[t]{2}{*}{ tech } & & & $0.019 * *$ & & & $0.021 * *$ \\
\hline & & & $(2.14)$ & & & $(2.46)$ \\
\hline \multirow[t]{2}{*}{ cost } & & & & & $-0.092 * *$ & $-0.102 * * *$ \\
\hline & & & & & $(-2.39)$ & $(-2.68)$ \\
\hline Control Variable & YES & YES & YES & YES & YES & YES \\
\hline Control Industry & YES & YES & YES & YES & YES & YES \\
\hline Control Year & YES & YES & YES & YES & YES & YES \\
\hline \multirow[t]{2}{*}{ Constant } & $0.768 * * *$ & $1.222 * * *$ & $0.746^{* * *}$ & $1.830 * * *$ & $0.936 * * *$ & $0.929 * * *$ \\
\hline & (32.77) & $(6.25)$ & (29.18) & $(41.32)$ & (12.67) & (12.74) \\
\hline Observations & 221 & 221 & 221 & 221 & 221 & 221 \\
\hline R-squared & 0.678 & 0.860 & 0.686 & 0.395 & 0.688 & 0.698 \\
\hline
\end{tabular}

Note: t-statistics in parentheses, ${ }^{* * *} p<0.01,{ }^{* *} p<0.05,{ }^{*} p<0.1$.

digital economy has a cost-cutting effect on the domestic value-added rate of manufacturing industry exports. In column (6), after including both tech and cost in the model, the significance level of the model is unchanged, and the estimated coefficient on the digital inputs variable has fallen further. Therefore, these results provide further evidence that technological progress and cost reductions are important mechanisms by which the digital economy promotes the domestic value-added rate of exports. Hypothesis Two is confirmed.

\section{CONCLUSION AND RECOMMENDATIONS}

Because the digital economy is booming and continues to inject new vitality into the traditional economy, this paper first elaborates the mechanisms by which the development of the digital economy effects the domestic value-added rate of exports from the perspective of technological progress and cost reductions. Then, Chinese manufacturing industry export DVAR as measured by the gross trade accounting method (Wang et al., 2013, 2015) and data from the WIOD are used to test the theoretical hypothesis. The results reveal several important facts. First, digital economic inputs have significantly increased the domestic value-added rate of manufacturing industry exports, which is conducive to increasing the real trade profit of the manufacturing industry. Second, further analysis finds that inputs from the digital economy have mainly increased the domestic value-added rate of intermediateproduct exports; that is, the development of the digital economy helps promote the optimization and upgrading of the export structure of the manufacturing industry. Third, the heterogeneity analysis results demonstrate that digital inputs have a significant positive effect on the capital-intensive and knowledge-intensive manufacturing industries. Fourth, the results of the intermediary effects analysis show that technological progress and cost reduction are vital mechanisms by which the digital economy promotes the domestic value-added rate of exports. 
This paper proposes the following policy recommendations for China and other export-oriented developing countries based on the research conclusions. First, these countries should encourage the deep application and integration of digital technology into the manufacturing industry in order to further optimize and improve the export trade structure and increase the domestic value-added rate of exports, which will increase the efficiency of economic growth and facilitate movement to the high end of the relevant value chains (Ding et al. 2019). Second, coverage of the digital economy should be expanded, with a focus on promoting the digital upgrade of capital-intensive and knowledge-intensive industries. This will ultimately lead to the transition from rapid economic growth to high-quality development. Finally, the government and enterprises should further encourage the use of digital economy inputs and should simultaneously make full use of the technological progress and cost reduction effects of digital economy inputs to further increase real export trade gains in manufacturing and to promote the optimization and upgrading of the manufacturing export trade structure. 


\section{REFERENCES}

Abelianskya, A. L., \& Hilbertb, M. (2017). Digital technology and international trade: Is it the quantity of subscriptions or the quality of data speed that matters? Telecommunications Policy, 41(1), 35-48. doi:10.1016/j. telpol.2016.11.001

Baron, R. M., \& Kenny, D. A. (1986). The moderator-mediator variable distinction in social psychological research: Conceptual, strategic, and statistical considerations. Journal of Personality and Social Psychology, 51(6), 1173-1182. doi:10.1037/0022-3514.51.6.1173 PMID:3806354

Brynjolfsson, E., Rock, D., \& Syverson, C. (2017). Artificial intelligence and the modern productivity paradox: A clash of expectations and statistics. NBER Working Paper, No. 24001.

Ceccobelli, M., Gitto, S., \& Mancuso, P. (2012). ICT capital and labor productivity growth:A nonparametric analysis of 14 OECD countries. Telecommunications Policy, 36(4), 282-292. doi:10.1016/j.telpol.2011.12.012

Chen, S. (2011). Reconstruction of sub-industrial statistical data in China (1980-2008). China Economic Quarterly, 10(03), 735-776.

Chen, Y., Lin, C., \& Chen, X. (2019). Artificial intelligence, aging and economic growth. Economic Research Journal, 54(07), 47-63. doi:10.1007/s00712-018-0623-3

Ding, Y., Zhang, H., \& Tang, S. (2019). The impact of US anti-dumping against China on China's manufacturing global value chains status. Transnational Corporations Review, 11(4), 323-331. doi:10.1080/19186444.2019 .1682408

Dunnewijk, T., \& Hultén, S. (2007). A brief history of mobile communication in Europe. Telematics and Informatics, 24(3), 164-179. doi:10.1016/j.tele.2007.01.013

Fan, Z., Zhang, Y., \& Peng, X. (2016). The geographical characteristics and the evolution of China's manufacturing GVCs: A study based on the upstream extension. Japan and the World Economy, 39(08), 118-142.

Fernandes, A. M., Mattoo, A., Nguyen, H., \& Schiffbauer, M. (2019). The internet and Chinese exports in the pre-ali baba era. Journal of Development Economics, 138, 57-76. doi:10.1016/j.jdeveco.2018.11.003

Garcia-Herrero, A., \& Xu, J.W. (2018). How big is China's digital economy? HKUST IEMS Working Paper No.2018-56.

Hall, R. E., \& Jones, C. I. (1999). Why do some countries produce so much more output per worker than others. The Quarterly Journal of Economics, 114(1), 83-116. doi:10.1162/003355399555954

Herlitschka, S., \& Valtiner, D. (2017). Digital transformation: How industry and society are remodeling as the analog becomes more and more digital. Elektrotechnik Und Informationstechnik, 134(7), 340-343. doi:10.1007/ s00502-017-0518-y

Hong, Y. (2017). Pivot to Internet Plus: Molding China's Digital Economy for Economic Restructuring? International Journal of Communication, 11, 1486-1506.

Judd, C. M., \& Kenny, D. A. (1981). Process analysis: Estimating mediation in treatment evaluations. Evaluation Review, 5(5), 602-619. doi:10.1177/0193841X8100500502

Knickrehm, M., Berthon, B., \& Daugherty, P. (2016). Digital disruption: The growth multiplier. Accenture Strategy.

Li, B., \& Li, R. (2017). Internet and firms' exports: Empirical evidence from China' s industrial enterprises. Japan and the World Economy, 40(07), 102-125.

Li, F. (2018). China's manufacturing industry and its governance and upgrading in the era of digital economybased on the global value chain framework (Doctoral dissertation). University of International Business and Economics.

Li, W., \& Yao, Y. (2015). Factor proportion, technical disparity and added value in exports-An empirical study on the Sino-U.S. bilateral trade. Finance \&Trade Economics, 98-111. 
Liu, Z. (2018). Research on industrial convergence in digital economy-based on manufacturing industry (Doctoral dissertation). University of International Business and Economics.

Luo, J. (2019). Imported producer services and manufacturing upgrading model in GVC: Influencing mechanism and moderating effects. Journal of International Trade, 65-79.

Ma, S., Guo, J., \& Zhang, H. (2019). Policy Analysis and Development Evaluation of Digital Trade: An International Comparison. China \& World Economy, 27(3), 49-75. doi:10.1111/cwe.12280

Ramli, M. K. R., \& Ismail, N. W. (2014). Role of infrastructures in explaining trade costs in ASEAN-5. Inzinerine Ekonomika-engineering Economics, 25(2), 119-129. doi:10.5755/j01.ee.25.2.2980

Shen, G., \& Yuan, Z. (2020). The effect of enterprise internetization on the innovation and export of Chinese enterprises. Economic Research Journal, 55(1), 33-48.

Shi, L., \& Wang, S. (2018). Analysis on the mechanism of internet promoting the development of China's foreign trade: Based on panel data from 31 provinces and cities. World Economy Studies, 48-59+132-133.

Tang, J., Wang, W., \& Yu, Z. (2020). Globalisation, ICT Investment and Firm Dynamism. Transnational Corporations Review, 12(2), 193-202. doi:10.1080/19186444.2020.1756724

Tian, Y. (2016). Estimation on capital stock of sectors in China:1990 2014. The Journal of Quantitative \& Technical Economics, 33(6), 3-21+76.

Venables, A. (2001). Geography and international inequalities: The impact of new technologies. Journal of Industry, Competition and Trade, 1(2), 135-159. doi:10.1023/A:1012830529827

Visser, R. (2019). The effect of the internet on the margins of trade. Information Economics and Policy, 46, 41-54. doi:10.1016/j.infoecopol.2018.12.001

Wang, Z., Wei, S., \& Zhu, K. (2013). Quantifying international production sharing at the bilateral and sector levels. NBER Working Paper 19677.

Wang Z., Wei S., \& Zhu K. (2015). Gross trade accounting method: Official trade statistics and measurement of the global value chain. Social Sciences in China, 108-127+205-206.

Wen, Z., \& Chang, L., Hau, K-T., \& Liu, H. (2004). Testing and application of the mediating effects. Acta Psychologica Sinica, 614-620.

Xu, H., Cheng, L., \& Sun, T. (2017). The effect of the input servitization of manufacturing on upgrading export domestic value added of enterprises-Empirical evidence from Chinese micro-enterprise. China Industrial Economics, 62-80.

Xu, J., \& Xu, Y. (2019). Do government subsidies affect enterprises' global value chain upgrading? From the perspective of export domestic value added raito. Journal of Financial Economics, 45(09), 17-29.

Yang, D., \& Liu, Y. (2018). Why can internet plus increase performance. China Industrial Economics, 80-98.

Zhang, S., \& Wei, X. (2019). Does information and communication technology reduce enterprise's energy consumption-Evidence from Chinese manufacturing enterprises survey. China Industrial Economics, $155-173$.

\section{ENDNOTES}

1 Data source: China's Digital Economy Development and Employment White Paper (2019), issued by the China Academy of Information and Communications Technology.

2 The manufacturing sector is subdivided into: (i) labor-intensive manufacturing (textiles, clothing apparel and leather products; wood and products of wood and cork, except furniture; articles of straw and plaiting materials; furniture; and other manufacturing), (ii) capital-intensive manufacturing (food products, beverages and tobacco products; paper and paper products, printing and the reproduction of recorded media; coke and refined petroleum products; rubber and plastic products; other nonmetallic mineral products; basic metals; and fabricated metal products except machinery and equipment), and (iii) 
knowledge-intensive manufacturing (chemicals and chemical products; basic pharmaceutical products and pharmaceutical preparations; computer, electronic and optical products; electrical equipment; machinery and equipment n.e.c.; and transport equipment).

The average number of laborers and the capital stock as measured by the perpetual inventory method were selected as input variable and the output variable is the total value of industrial output (the industrial producer price index is used for deflating by industry).

4 Since there is an endogenous relationship between R\&D intensity and technological progress in an economic sense, Table 8 no longer includes the R\&D intensity variable.

Ding Yibing is a PhD in economics. He is now Dean of the School of Economics, Professor of the Department of International Economics and PhD supervisor of Jilin University. He went to give lectures at Chonnam National University in South Korea from December 2006 to January 2007. He went to Vrije Universiteit Amsterdam for research visits from January 2007 to April 2007. He went to Stanford University to study as a Fulbright visiting scholar from 2010.09 to 2011.09. He received the Liu Shibai Economics Award from the Liu Shibai Economics Award Foundation in September 2016. His main research fields are international finance and international trade.

Zhang Hongyuan is now a PhD student in the School of Economics of Jilin University. She graduated from the Department of International Economics and Trade of Jilin University School of Economics in 2017. As an exchange student, she went to the Department of International Economics and Trade of Xiamen University from September 2014 to September 2015 to study. In August 2016, she was funded by Yonggeng Charity Fund to participate in student exchange activities at the University of Berkeley in the United States. In November 2019, she was funded by Jilin University to go to Italy for research and study. She has won two first-class scholarships for outstanding graduate students of Jilin University. Her current main research areas are international trade issues and issues related to global value chains.

Tang Sitong received his undergraduate degree in Economics in University of Liverpool and Xi'an Jiaotong- Liverpool University in 2017. He further obtained a master degree in Economics in University of Edinburgh in 2018. He is now studying Global Environmental Studies in the Sophia University in Tokyo, Japan. Tang's research focuses on issues related to international trade and international affairs. 